and overcame opposition in improving their lot. For many years he assessed patients for entitlement to attendance allowance and until his terminal illness he was a civilian medical practitioner in HMS Drake, a shore establishment in Devonport.

He was fearlessly honest and an uncompromising critic of carelessness and fudge but a charming and resourceful gentleman who gave his patients the great benefits of his wisdom and undivided attention, care and compassion. He married in 1958 and he and his wife, Mary, settled in an old vicarage in rural Devon. He was a devoted husband, father and stepfather.

He died on 22 December 1991 after an illness which he accepted with his usual courage and humour.

Geoffrey Wallis

\section{Hugh de Broe WarRen, formerly Consultant Psychiatrist to the York Health Authority}

Dr Warren died in York on 24 February 1992, aged 69 , following a long and very distressing illness. In his latter years he showed great courage and determination in order to keep going, and until fairly recently was attending meetings at the Postgraduate Centre, and the York Medical Society, of which he was a past president.

Hugh was born in London, and was educated at Wellington College and St Bartholomews Hospital, where he qualified MB BS (Lond) in 1946 after which he did his national service in the Royal Air Force Medical Branch.

His early years in psychiatry were spent mainly at Netherne and Goodmayes Hospitals. He obtained the DPM in 1956 and was elected MRCPsych in 1971 and elevated to the fellowship in 1977.
His first consultant post was at St Andrews, Northampton, where he stayed for eight years. From there he moved to the United States as Clinical Director at Gracey Square Hospital, New York, where he worked with Lother V. Kalinowsky.

On returning to the UK he was appointed a Consultant to Bootham Park and Naburn Hospitals in York where he remained until he retired.

Hugh was interested in teaching and for some years was a part-time lecturer in the Department of Psychiatry, Leeds University, and at St John's College, York. But it was his registrars to whom he gave the benefit of his broadly-based knowledge. They describe him as a teacher who would always listen and then add that little extra sentence or an idea that would finally clinch a diagnosis and put their thinking into context.

At Bootham Park he especially enjoyed working with neurological colleagues at the Neuro-Psychiatric Unit, and latterly, when Naburn was due to close, he was instrumental in moving the Mother/Baby Unit to purpose-built premises at Bootham Park near to the main paediatric services.

A very private person, Hugh is described by those who knew him best as a most caring father and friend. He was married twice. Audrey, his first wife and he had three sons and a daughter and they were to see two of his sons and a grandson die tragically. The son and daughter of his second marriage to Willa, and a stepson were to complete his large family.

Sport was one of Hugh's interests and he enjoyed nothing more than his ski-ing holidays. His pleasure in cars was shared by many of his colleagues and friends. His other great pastime was music, and sometimes he could be seen in the Minster listening to the organ, often being played by his stepson, Garry.

JOYCE GALBRAITH

\title{
Mr Alastair Ross
}

We regret to announce the death on 2 April 1992 of Mr Alastair Ross, late of the Board of Control. An interview with him was published in the April 1992 issue of the Psychiatric Bulletin. 